\title{
Selective incorporation of dissolved organic matter (DOM) during sea ice formation
}

\author{
Susann Müller ${ }^{\mathrm{a}, *}$, Anssi V. Vähätalo ${ }^{\mathrm{b}}$, Colin A. Stedmon ${ }^{\mathrm{c}}$, Mats A. Granskog ${ }^{\mathrm{d}}$, Louiza Norman ${ }^{\text {e,f }}$, \\ Shazia N. Aslam ${ }^{\text {g }}$, Graham J.C. Underwood ${ }^{\mathrm{g}}$, Gerhard S. Dieckmann ${ }^{\mathrm{h}}$, David N. Thomas ${ }^{\text {f,i,j }}$ \\ a University of Helsinki, P.O. Box 65, Viikinkaari 1, FI-00014 Helsinki, Finland \\ ${ }^{\mathrm{b}}$ University of Jyväskylä, Department of Biological and Environmental Science, 40500 Jyväskylä, Finland \\ c Technical University of Denmark, National Institute of Aquatic Resources, Kavalergården 6, 2920 Charlottenlund, Denmark \\ d Norwegian Polar Institute, Fram Centre, NO-9296 Tromsø, Norway \\ e University of Technology Sydney, Broadway, Sydney, New South Wales 2001, Australia \\ ${ }^{f}$ School of Ocean Sciences, Bangor University, Menai Bridge, Anglesey LL59 5AB, UK \\ ' School of Biological Sciences, University of Essex, CO4 3SQ Colchester, UK \\ ${ }^{\mathrm{h}}$ Alfred Wegener Institute for Polar and Marine Research, Am Handelshafen 12, D-27570 Bremerhaven, Germany \\ ${ }^{i}$ Finnish Environment Institute (SYKE), Marine Research Centre, P.O. Box 140, 00251 Helsinki, Finland \\ j Arctic Centre, Aarhus University, DK-8000 Aarhus C, Denmark
}

\section{A R T I C L E I N F O}

\section{Article history}

Received 25 February 2013

Received in revised form 19 June 2013

Accepted 27 June 2013

Available online 10 July 2013

\section{Keywords:}

Sea ice

Selective rejection

Chromophoric dissolved organic matter

(CDOM)

Excitation emission fluorescence

spectroscopy

Frost flowers

\begin{abstract}
A B S T R A C T
This study investigated the incorporation of DOM from seawater into $<2$ day-old sea ice in tanks filled with seawater alone or amended with DOM extracted from the microalga, Chlorella vulgaris. Optical properties, including chromophoric DOM (CDOM) absorption and fluorescence, as well as concentrations of dissolved organic carbon (DOC), dissolved organic nitrogen (DON), dissolved carbohydrates (dCHOs) and dissolved uronic acids (dUAs) were measured. Enrichment factors (EFs), calculated from salinity-normalized concentrations of DOM in bulk ice, brine and frost flowers relative to under-ice water, were generally $>1$. The enrichment factors varied for different DOM fractions: EFs were the lowest for humic-like DOM (1.0-1.39) and highest for amino acid-like DOM (1.10-3.94). Enrichment was generally highest in frost flowers with there being less enrichment in bulk ice and brine. Size exclusion chromatography indicated that there was a shift towards smaller molecules in the molecular size distribution of DOM in the samples collected from newly formed ice compared to seawater. Spectral slope coefficients did not reveal any consistent differences between seawater and ice samples. We conclude that DOM is incorporated to sea ice relatively more than inorganic solutes during initial formation of sea ice and the degree of the enrichment depends on the chemical composition of DOM.
\end{abstract}

(c) 2013 Elsevier B.V. All rights reserved.

\section{Introduction}

When seawater freezes and sea ice forms, dissolved organic and inorganic matter is excluded from the crystalline ice structure and concentrates in the liquid brine phase. Brine may then drain into the water below, be involved in the formation of frost flowers on top of the ice, or remain trapped in brine channels and pockets within the sea ice (Petrich and Eicken, 2010). The quantity and chemical characteristics of brine affect both the spatial and temporal variabilities in the physico-chemical characteristics of sea ice, as well as the habitats for biological assemblages within ice (Thomas and Dieckmann, 2002). Dissolved organic matter (DOM) in brine is a major source of energy and nutrients for heterotrophic organisms within ice, and also significantly influences the optical properties of sea ice (Thomas and

\footnotetext{
* Corresponding author. Tel.: + 358 445155646; fax: + 358919158257.

E-mail address: susann.mueller@helsinki.fi (S. Müller).
}

Dieckmann, 2010 and citations therein). When chromophoric DOM (CDOM) in brine absorbs ultraviolet radiation (UVR) and photosynthetically active solar radiation, it influences the energy budget of ice, the light availability and UVR exposure of organisms within and below the ice (Uusikivi et al., 2010).

In sea ice brines the concentration of DOM varies depending on brine volume (Petrich and Eicken, 2010; Thomas and Dieckmann, 2010): decreasing temperatures reduce the volume of brine and in turn increase the salinity and the concentrations of DOM in the brines above those in seawater. In contrast, when bulk ice, consisting of pure ice crystals and brine is melted, the concentrations of solutes (e.g., salinity and DOM) are lower in melted bulk ice than in seawater, because brine makes up only a small fraction of the total volume of ice. In order to assess the changes in the quantity of DOM in sea ice, without the effect of varying temperatures or sampling methods (brine vs. melted ice), the concentration of DOM in sea ice is frequently normalized to salinity (Giannelli et al., 2001; Granskog et al., 2004; Patsayeva et al., 2004; 
Müller et al., 2011). This has revealed that the DOM content of sea ice may include DOM from algal and bacterial production in sea ice (autochthonous; Underwood et al., 2010; Aslam et al., 2012a) in addition to that what is trapped in ice during its formation (allochthonous, Stedmon et al., 2007, 2011).

Previously studies have suggested that DOM does not necessarily behave conservatively during formation of sea ice compared to other dissolved constituents such as inorganic ions. As a consequence the concentration of salinity normalized DOM can be higher (or enriched) in sea ice compared with the under-ice water (Giannelli et al., 2001; Granskog et al., 2004; Patsayeva et al., 2004; Müller et al., 2011). Despite these findings relatively little is known about the mechanisms of enrichment during ice formation. One explanation is that the enrichment of DOM depends on different diffusion rates of solutes to brine leaving sea ice through gravity drainage (Gross et al., 1987; Reeburgh and Springer-Young, 1983). Such gravity drainage of brine may preferentially remove most small molecules, such as inorganic ions, which diffuse at faster rates than DOM molecules with larger size and lower diffusion rates (Granskog et al., 2004; Vancoppenolle et al., 2010; Maus et al., 2011). Another explanation suggests that bacterial and algal extracellular polymeric substances (EPSs) form gel-like structures that selectively retain DOM in sea ice (Raymond et al., 2007; Underwood et al., 2010; Krembs et al., 2011). Therefore, experimental evidence is needed to resolve the process of the enrichment of DOM during ice formation, especially considering the enormous volume of sea ice that forms, consolidates and subsequently melts in polar and sub-polar oceans and seas.

The present study addresses a potential enrichment of DOM during the first $48 \mathrm{~h}$ of ice growth in $1.2 \mathrm{~m}^{3}$ experimental mesocosms placed in a large environmentally controlled ice tank facility (at the Hamburg Ship Model Basin HSVA: http://www.hsva.de). Absorption and fluorescence of CDOM, the concentration of dissolved organic carbon (DOC), dissolved organic nitrogen (DON) and dissolved carbohydrates (dCHOs) and uronic acids (dUAs) were analyzed from seawater, melted bulk ice, brine and frost flowers to quantify different DOM fractions. Changes in the optical quality and the molecular size of DOM during the formation of ice were investigated using analyses of the spectral slope coefficients and size-exclusion chromatography of the CDOM. The seawater used was collected from the North Sea, but in order to change both the quantitative and qualitative nature of the DOM, high concentrations of DOM derived from disrupted algal cells were added to half of the mesocosms. This enabled us to address the question of whether or not the quality of DOM affects the incorporation into sea ice. Aslam et al. (2012b) used the same experiment to investigate the effect of algal-DOM addition on bacterial communities and the production and dynamics of EPS. They described an incorporation of DOC and POC from the under-ice water into sea ice and the following change in the bacterial growth. The focus of the present study is to evaluate the abiotic incorporation of DOM from seawater to sea ice during the initial stages of ice growth where there was a minimal chance for the biological transformation of DOM (Aslam et al., 2012b). We describe a novel combination of methods that describe quantitative and qualitative changes of DOM during the initial ice formation. Understanding physico-biogeochemical processes during the ice formation are necessary to evaluate changes in the biomass, species composition and biochemistry of sea ice and help to estimate future conditions.

\section{Materials and methods}

\subsection{Experimental design and sampling routine}

North Sea water was sampled by ship near Helgoland ( $54^{\circ} 11^{\prime} \mathrm{N}$, $7^{\circ} 55^{\prime} \mathrm{E}$ ) and transported in a cleaned (food-quality) road tanker to the HSVA test basin within $24 \mathrm{~h}$, at a water temperature of $13 \pm 1{ }^{\circ} \mathrm{C}$. Algal organic matter was produced by melting a frozen paste of freshwater algae Chlorella vulgaris (Varicon Aqua Ltd, U.K.) in artificial seawater with a salinity of 34 . The suspension was sonicated in $500 \mathrm{ml}$ batches at a sample temperature of $0{ }^{\circ} \mathrm{C}$ using a Branson 450 Digital Sonifier (Branson Ultrasonics Corporation, Danbury, CT, USA). All suspensions were pooled and centrifuged at 12,235 g in a Beckmann Coulter centrifuge. The supernatant (algal-DOM) was collected and kept frozen $\left(-18{ }^{\circ} \mathrm{C}\right)$ until use. In this stock solution, the concentration of algal-derived DOC was $550 \mathrm{mmol} \mathrm{L}^{-1}$.

The experimental setup consisted of 18 polyethylene (PE) bags supported by floating frames in an environmental test basin (Fig. 1). Each mesocosm was filled with $1.2 \mathrm{~m}^{3}$ of unfiltered North Sea water on September 30th 2009. $900 \mathrm{ml}$ of the algal-DOM of the stock solution was added to nine of the mesocosms (hereafter called SW $+\mathrm{A}$ ), while the remaining mesocosms with just North Sea water are hereafter referred to as SW. All mesocosms were left to cool and mix (each mesocosm had a simple submerged pump installed), and initial samples were collected on the first sampling day (d0) on the 2nd of October after more than $24 \mathrm{~h}$ of mixing. Freezing was initiated on d3 by spraying a fine mist of Milli-Q water $(<1$ L over whole environmental test basin) over the water surface (Giannelli et al., 2001) after the air temperature had been lowered to $-13{ }^{\circ} \mathrm{C}$, which was subsequently maintained for the rest of the experiment $\left( \pm 2{ }^{\circ} \mathrm{C}\right)$. A polyvinyl chloride (PVC) tube was installed in each bag which was cleared of ice each day to maintain pressure equilibrium and ensure that the water was always in contact with the bottom of the ice, as well as to provide a convenient portal through which to sample under-ice water.

Water samples were collected from all mesocosms on d3, and thereafter water, ice and brine samples were collected from randomly chosen mesocosms on $\mathrm{d} 4$ and $\mathrm{d} 5$ with 1 to 3 replicates per treatment and sampling day. Each mesocosm was only sampled for ice and brine on one occasion, as the sampling compromised the integrity of the ice making the sampled mesocosm redundant (Fig. 1). Frost flowers were collected on d5. For the bulk ice samples, ice blocks were sawed from the ice sheet, floated carefully away from the remaining ice and sectioned within a minute into 2-3 layers depending on the ice thickness. This technique was employed to minimize the losses of brine that are characteristic of normal ice coring. The saw was cleaned before each use by sawing through other ice from the same depth horizon. The ice was melted at room temperature within $12 \mathrm{~h}$ in acid-washed PE buckets with the temperature of melt water never reaching above $0{ }^{\circ} \mathrm{C}$. Since the present study focused on the

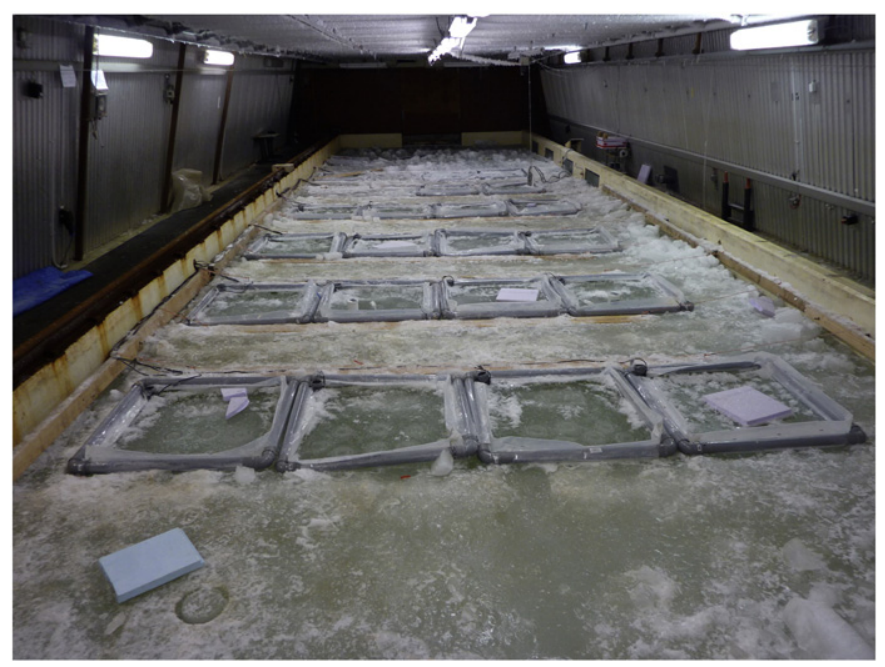

Fig. 1. The experimental mesocosms floating in an environmentally controlled ice tank of the Hamburg Ship Model Basin. The foam pads on some of the mesocosms mark the compromised ones after they have been sampled. Note that the lights were on only during sampling (at maximum $2 \mathrm{~h}$ per day) and the rest of the time, the tanks were in darkness. 
whole ice layer in comparison to under-ice water, we calculated a mean of measurements from all vertical ice layers in each mesocosm.

For brine sampling, sack holes (described by Papadimitriou et al., 2007) were drilled to a $6 \mathrm{~cm}$ depth with a Cherepanov ice ring of $20 \mathrm{~cm}$ diameter. Within $30 \mathrm{~min}$ after the drilling, brine was collected from each sackhole using cleaned Teflon tubing and $20 \mathrm{ml}$ syringes (without rubber parts) and these samples were processed in $<4 \mathrm{~h}$. Frost flowers were collected using the rim of an acid-washed PE container for scraping them from the ice surface. The frost flowers were melted at room temperature within $1 \mathrm{~h}$, with the melt water never rising above $0{ }^{\circ} \mathrm{C}$, and again these samples processed in $<4 \mathrm{~h}$.

\subsection{Sample treatment and analyses}

Temperatures of water and brine were measured with a recently calibrated Testo® 110 thermometer. Temperatures ranged from $0.6{ }^{\circ} \mathrm{C}$ on $\mathrm{d} 0$ to $-1.9{ }^{\circ} \mathrm{C}$ on $\mathrm{d} 5$ in water and from $-3.1{ }^{\circ} \mathrm{C}$ to $-6{ }^{\circ} \mathrm{C}$ in the brines. Optical properties of DOM were measured from $0.2 \mu \mathrm{m}$ filtered (Millex-syringe filters; Millipore ${ }^{\circledR}$ ) samples. Samples for a liquid chromatography-size exclusion chromatography (LC-SEC) analysis were stored in pre-combusted glass scintillation vials in the dark at $4{ }^{\circ} \mathrm{C}$. Samples for DOC and DON were filtered through pre-combusted Whatman ${ }^{\circledR} \mathrm{GF} / \mathrm{F}$ filters and the filtrates were kept at $-20{ }^{\circ} \mathrm{C}$ until analyses. Salinity was measured using a SEMAT ${ }^{\circledR}$ Cond 315i/SET salinometer with a WTW Tetracon 325 probe at room temperature (Aslam et al., 2012b). DOC was measured by high temperature combustion on a MQ1000 TOC analyzer (Qian and Mopper, 1996), following the methods of Norman et al. (2011). DON was calculated by the subtraction of nitrate and ammonium from the total dissolved nitrogen (TDN). TDN was measured by standard colorimetric methodology (Grasshoff et al., 1983) on a LACHAT Instruments Quick-Chem 8000 autoanalyser (see Papadimitriou et al. (2007) for further details). Samples for dissolved carbohydrate ( $\mathrm{dCHO}$ ) analysis were desalted by dialysis ( $8 \mathrm{kDa}$ membrane) against Milli-Q water (final salinity $<1$ ), freeze dried and stored at $-20{ }^{\circ} \mathrm{C}$. Concentrations of $\mathrm{dCHO}$ were determined according to Underwood et al. (2010) and Aslam et al. (2012b). A standard carbazole assay was used to measure the concentration of dUA (Bellinger et al., 2005; Aslam et al., 2012b).

Absorption spectra of CDOM were measured in a $10 \mathrm{~cm}$ quartz cell over a 200 to $700 \mathrm{~nm}$ range in $1 \mathrm{~nm}$ increments and a slit width of $2 \mathrm{~nm}$ with a Shimadzu UV-2101 spectrophotometer. After the samples had warmed to room temperature, three replicates of each sample were measured against ultrapure water (MilliQ, resistivity $=18.2 \mathrm{M} \Omega \cdot \mathrm{cm}$ ) blank. $\mathrm{CDOM}$ was described by the absorption coefficient, $a\left(\mathrm{~m}^{-1}\right)$, at wavelength $\lambda(\mathrm{nm})$ that was calculated using

$a_{\mathrm{CDOM}, \mathrm{\lambda}}=2.303 A_{\lambda} 0.1^{-1}$,

where $A_{\lambda}$ is the mean absorbance at wavelength $\lambda$.

The spectral slope coefficient $S\left(\mu \mathrm{m}^{-1}\right)$ for the ranges $250-450 \mathrm{~nm}$, 275-295 nm and 350-400 nm was calculated by using a nonlinear fit in Matlab based on the following equation (Stedmon et al., 2000):

$a_{\mathrm{CDOM}, \lambda}=a_{\lambda, 0} \mathrm{e}^{S(\lambda, 0-\lambda)}$,

where $a_{\lambda, 0}$ is the absorption coefficient at the wavelength $\lambda, 0$ describing the shortest end of spectral range. The coefficients of determination for the fits were $>0.99$. The slope ratio $\left(S_{R}\right)$ was the ratio of $S_{275-295}$ to $S_{350-400}$ (Helms et al., 2008).

Fluorescence was measured in a $1 \mathrm{~cm}$ quartz cell using a Varian Cary Eclipse spectrofluorometer with an integration time of $0.1 \mathrm{~s}$ and a scan speed of $1200 \mathrm{~nm} \mathrm{~min}{ }^{-1}$. The voltages changed depending on the concentration of the sample between 850 and $1000 \mathrm{~V}$ but were corrected later by calibration to the Raman scatter signal (Lawaetz and Stedmon, 2009). Excitation ranged from 240 to $450 \mathrm{~nm}$ in $5 \mathrm{~nm}$ increments and emission from 300 to $550 \mathrm{~nm}$ with $2 \mathrm{~nm}$ increments. The slit width was set to $5 \mathrm{~nm}$ for excitation and emission scans. Measurements and instrumental corrections were done according to Stedmon and Bro (2008). Excitation emission matrices (EEMs) of all 116 samples were characterized by 6 fluorescent components using parallel factor analysis (PARAFAC) and the DOMFluor toolbox (Stedmon and Bro, 2008). The components were validated by split half analysis and random initialization. The fluorescence intensities in the subsequent data analysis refer to the maxima fluorescence signals of each component (Fmax).

The molecular size distribution of CDOM was analyzed by LC-SEC as described by Müller et al. (2011) using a TSK G3000SWxl column ( $7.8 \mathrm{~mm} \times 30 \mathrm{~cm}, 250 \AA$ pore size, $5 \mu \mathrm{m}$ particle size) and a TSK guard column $(7.5 \mathrm{~mm} \times 7.5 \mathrm{~mm})$, with a $\mathrm{KH}_{2} \mathrm{PO}_{4}\left(2.7 \mathrm{~g} \mathrm{~L}^{-1}\right)$ and $\mathrm{Na}_{2} \mathrm{HPO}_{4} \cdot 2 \mathrm{H}_{2} \mathrm{O}$ (3.56 g L ${ }^{-1}, \mathrm{pH} 6.85$ ) buffer. Measurements were performed using absorbance detection at $254 \mathrm{~nm}$ with a Hewlett Packard 1100 series high-performance liquid chromatography (HPLC) instrument. All samples were diluted with ion-exchanged Milli-Q water to a final salinity of 9 to avoid a shift in molecular size due to changes in salinity (Specht and Frimmel, 2000; Her et al., 2002). A baseline correction was performed by normalizing all chromatograms to the absorption at the retention time (Rt) of $12 \mathrm{~min}$. Salinity-normalization was done by setting the salinity-dependent maximal value of each sample to 1 (Minor et al., 2002). Rts were $7.7 \mathrm{~min}$ for Blue Dextran $2000\left(2 \times 10^{6} \mathrm{~g} \mathrm{~mol}^{-1}\right), 16.3 \mathrm{~min}$ for tyrosine $\left(181.2 \mathrm{~g} \mathrm{~mol}^{-1}\right), 16.5 \mathrm{~min}$ for phenylalanine $\left(165.1 \mathrm{~g} \mathrm{~mol}^{-1}\right)$ and between 12 and $15.5 \mathrm{~min}$ for Nordic fulvic acid (Müller et al., 2011). We limited our interest in the range of Rt from 13.5 to 15.5 min representing the molecular size fraction of fulvic acids.

Salinity-normalized concentrations of DOM fractions collected from different compartments of ice or water $\left(X_{n o r m, i}\right)$ were calculated by:

$X_{\text {norm }, i}=\frac{X_{i}}{S_{i}} 33$,

where $X$ represents the DOM fraction (DOC, DON, dCHO, dUA, CDOM or maximum intensities of fluorescent components), the subscript $i$ represents the sample type (water, bulk ice, brine or frost flowers) and 33 was the initial salinity of North Sea water.

The enrichment factor of DOM fractions, $E F(X, i)$, was calculated by:

$E F(X, i)=\frac{X_{\text {norm }, i}}{X_{\text {norm,water }}}$

where $X_{n o r m, i}$ and $X_{\text {norm,water }}$ are the salinity normalized concentrations of the DOM fractions in each sample type and in water below the ice, respectively. $E F(X)$ notation refers to DOM fractions specified by $X$ without referring to any specific type of sample collected from ice. If $E F>1$, a DOM fraction in ice is considered to be enriched and conversely a $E F<1$ represents depletion relative to seawater.

The main aim in this study was to assess potential changes in DOM during its incorporation to newly formed sea ice. For this assessment we compared samples collected from sea ice (bulk ice, brine or frost flowers) to samples collected from water using t-tests for independent samples (SPSS; $\mathrm{p} \leq 0.05$ ).

\section{Results}

\subsection{Characterization of initial water}

The addition of algal-DOM to North Sea water changed the absorption spectrum of CDOM, the excitation-emission matrix (EEM) of fluorescent DOM and the size distribution of humic-like dissolved organic 
matter (Fig. 2). The algal-DOM had little influence on CDOM absorption at wavelengths above $300 \mathrm{~nm}$, except for a small peak at $410 \mathrm{~nm}$ (14\% increase), however, the absorption at $255 \mathrm{~nm}$ doubled (Fig. 2a). The spectral slope coefficient $S_{250-450}$ was $18.1 \pm 0.3 \mu \mathrm{m}^{-1}$ ( \pm refers to standard error throughout the results) in the SW mesocosms, but higher $\left(26.6 \pm 0.1 \mu^{-1}\right)$ in the mesocosms with algal-DOM, because the lower spectral range of $S_{250-450}$ matched an absorption peak of algal-DOM (Fig. 2a). $S_{R}$ values were $1.19 \pm 0.04$ in the $S W$ treatment and $1.96 \pm 0.04$ in the $\mathrm{SW}+\mathrm{A}$-treatment. The addition of algalDOM increased the intensity of fluorescence at shorter emission wavelengths (Fig. 2b). After the addition of algal-DOM, the size distribution chromatography showed an increase in the absorbance by $4 \%$ at the retention time of 14.6 (peak 1) and by $22 \%$ at the retention time of 15.2 min (peak 2; Fig. 2c). The molecular size distribution was therefore shifted towards smaller molecules in the SW + A treatment. The addition of algal-DOM increased the initial concentrations of DON from $3.9 \pm 0.2 \mu \mathrm{mol} \mathrm{L}{ }^{-1}$ to $44.1 \pm 1 \mu \mathrm{mol} \mathrm{L}^{-1}$. The corresponding change for DOC was from $109.4 \pm 3.2 \mu \mathrm{mol} \mathrm{L}^{-1}$ to $380 \pm$ $5.1 \mu \mathrm{mol} \mathrm{L}{ }^{-1}$. dCHO concentrations were $25.2 \pm 1.3 \mu \mathrm{mol} \mathrm{L}{ }^{-1}$ and $31.7 \pm 1.1 \mu \mathrm{mol} \mathrm{L}{ }^{-1}$ in the SW- and SW + A treatments, respectively,
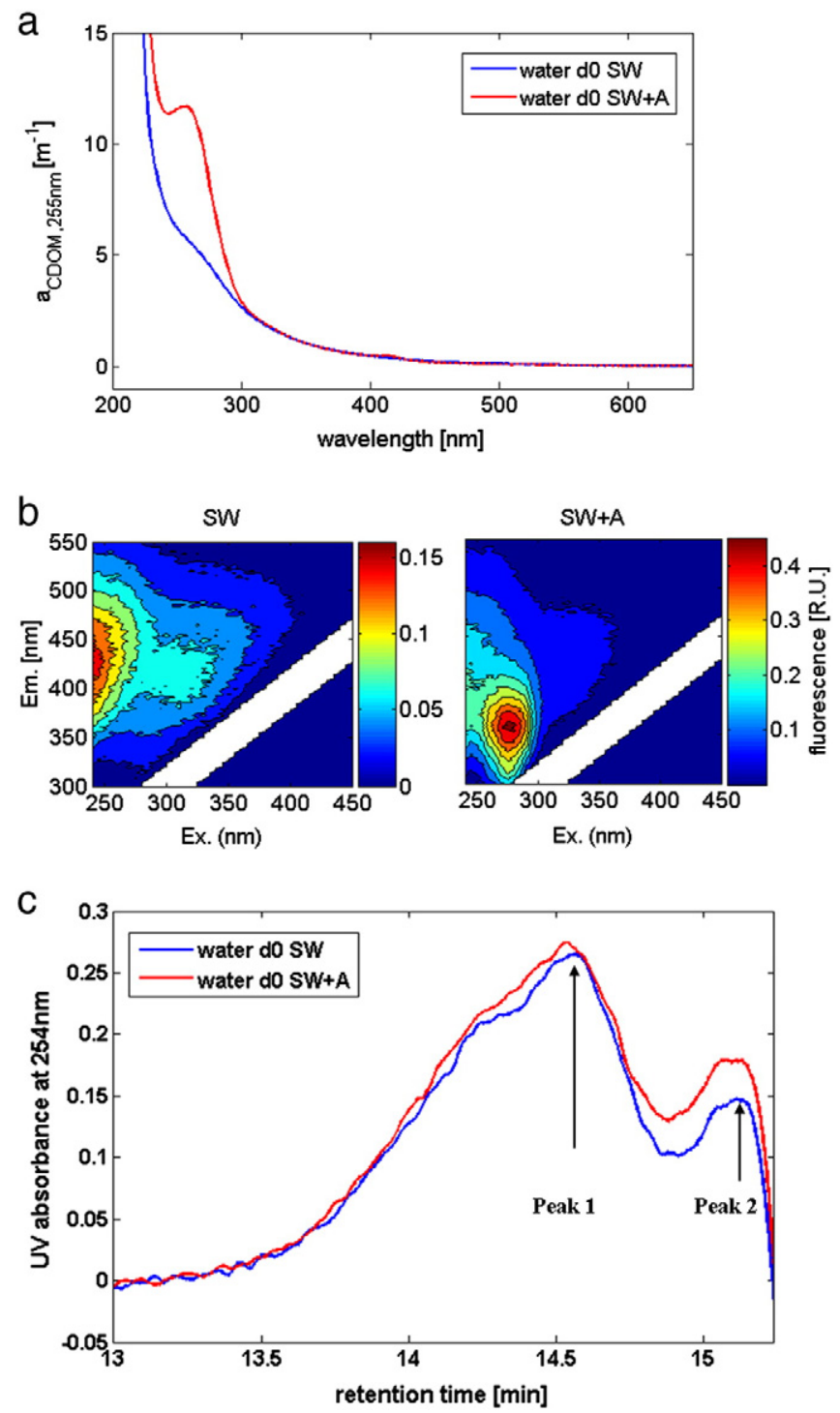

Fig. 2. The initial $C D O M$ absorption spectra (a) fluorescence exitation emission matrices (b) and LC-SEC chromatograms (c) in North Sea water alone (SW) and with algal-DOM added $(\mathrm{SW}+\mathrm{A})$. The curves for CDOM (a) and LC-SEC (c) show means $(n=7-8)$. The standard errors (SEs) of means were less than the thickness of curves. and the concentrations of dUA were $13.7 \pm 0.7 \mu \mathrm{mol} \mathrm{L} \mathrm{L}^{-1}$ and $17.6 \pm$ $1.4 \mu \mathrm{mol} \mathrm{L} \mathrm{L}^{-1}$ in the SW- and SW + A treatments, respectively.

The PARAFAC modeling of fluorescent DOM (FDOM) separated the pool of FDOM into 6 components (Fig. 3a): C2 (ex/em $=340 / 430$ and 240/430), C3 (310/385 and 240/385) and C4 (245/500 and 380/500) were similar to humic-like components (Coble, 1996; Murphy et al., 2008; Yamashita et al., 2010; Stedmon et al., 2011). The remaining components had characteristics similar to amino acids. C5 (ex/em $=275$ / 315) was similar to a tyrosine-like component (Murphy et al., 2008), while C1 (280/360) and C6 (240/350 and 290/350) were similar to tryptophan-like components which have excitation maxima below $240 \mathrm{~nm}$ and at $275 \mathrm{~nm}$ and an emission maximum at $350 \mathrm{~nm}$ (Stedmon and Markager, 2005; Murphy et al., 2008; Stedmon et al., 2011).

In the $\mathrm{SW}+\mathrm{A}$ treatment waters, the intensity of fluorescence was highest for C1 (Fig. 3b). The PARAFAC analysis of FDOM indicated that the introduction of algal-DOM increased the concentrations of amino acid-like DOM up to 16 -fold and humic-like DOM up to 1.3 -fold (Fig. 3b).

\subsection{Dynamics of salinity during the experiment}

The experiment consisted of the cooling phase ( $d 0$ to $\mathrm{d} 3$ ) prior to the ice formation and the freezing phase with the first two days of ice (d4 and d5, indicated by the grey background in Fig. 4). The development of the ice thickness and the salinity was similar in both treatments (Fig. 4 inset). The salinity of the four different sample types (water, bulk ice, brine and frost flowers) showed large differences mainly caused by the exclusion of salts from bulk ice and their enrichment in brine (Fig. 4). In order to compare the behavior of DOM fractions $(X)$ across the sample types with different salinity, their concentrations were normalized to the initial salinity of seawater which was 33 (Eq. (3)).

\subsection{Quantitative changes in DOM during freezing}

$D O C_{\text {norm }}$ and $D O N_{\text {norm }}$ decreased throughout the experiment in the SW + A but not in the SW-treatment and were typically significantly higher in bulk ice, brine and frost flowers than in water as indicated by the asterisks in Fig. 5 . These results indicate that $D O C_{\text {norm }}$ and $D O N_{\text {norm }}$ were generally enriched in all sample types collected from sea ice relative to water. $E F(D O C)$ or $E F(D O N)$ for the samples collected from ice (bulk ice, brine, frost flowers) ranged from 1.08 to 3.64 (Fig. 6a-d; Eq. (4)).

After the formation of ice, $C D O M_{\text {norm }}$ was consistently higher in bulk ice and frost flowers than in water (Fig. 7a-b). EF(CDOM) of all sample types ranged from 0.96 to 1.30 (Fig. 6 e-f).

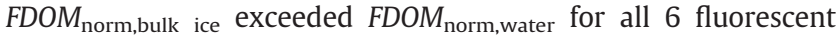
components in the SW-treatment, but only for C4 and C6 in the SW + A-treatment (Fig. 8 left column and Fig. $8 \mathrm{~h}$ and l, respectively). In the SW $+\mathrm{A}$-treatment, $C 1_{\text {norm }}$ of bulk ice was lower than that in SW indicating a depletion of C1 in bulk ice (Fig. 8b). The enrichment factors for the fluorescent components ranged from 0.83 to of 7.45 (Fig. 6g-r).

After the ice formation, $d C H O_{\text {norm }}$ and $d U A_{\text {norm }}$ were typically higher in the bulk ice than in water (Fig. 9a-d). $d U A_{\text {norm,brine instead }}$ was lower $d U A_{\text {norm,water }}$ (Fig. 9c-d). The enrichment factors for $\mathrm{dCHO}$ and dUA ranged from 0.99 to 2.54 in bulk ice and from 0.5 to 1.01 in brine (Fig. 6s-v).

\subsection{Changes in spectral slope and molecular size distribution}

Spectral slopes and slope ratios calculated for ice samples were generally similar to those measured in water (Fig. 7c-j), however, in a few cases the slopes were significantly different between water and bulk ice, brine or frost flowers (Fig. 7e-j). These differences 
a
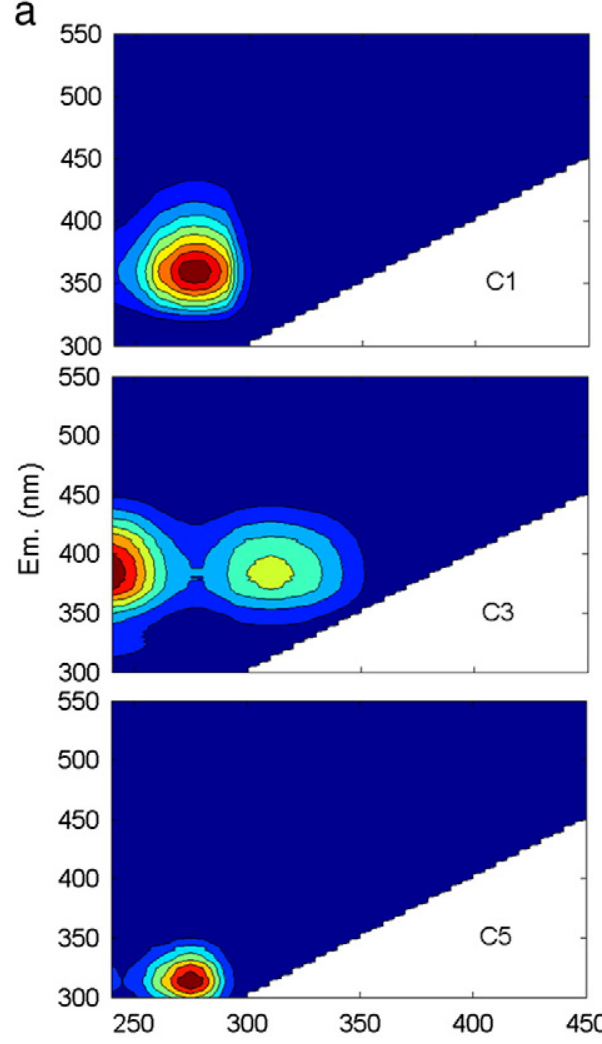

b

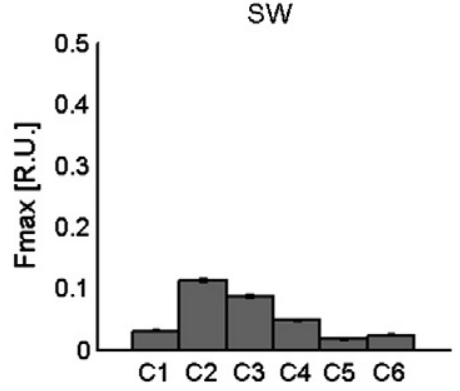

450250
Ex. $(\mathrm{nm})$
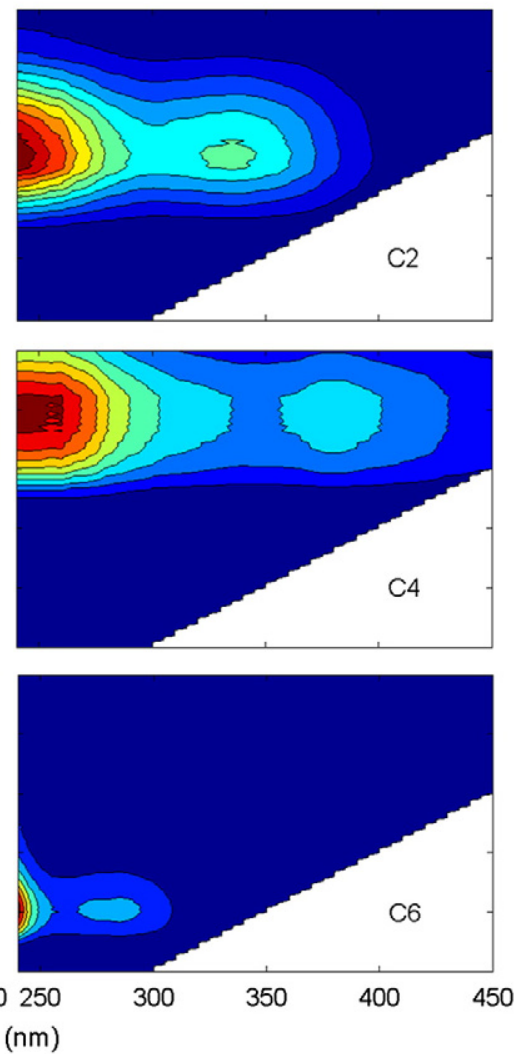

$S W+A$

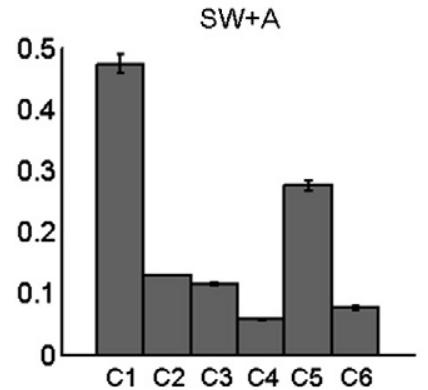

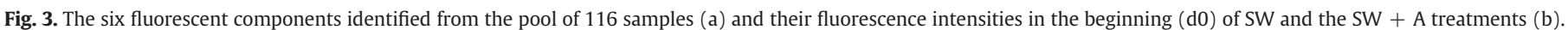
Fmax refers to mean \pm SE of maximum fluorescent intensities of each component in the replicated mesocosms $(n=7-8)$.

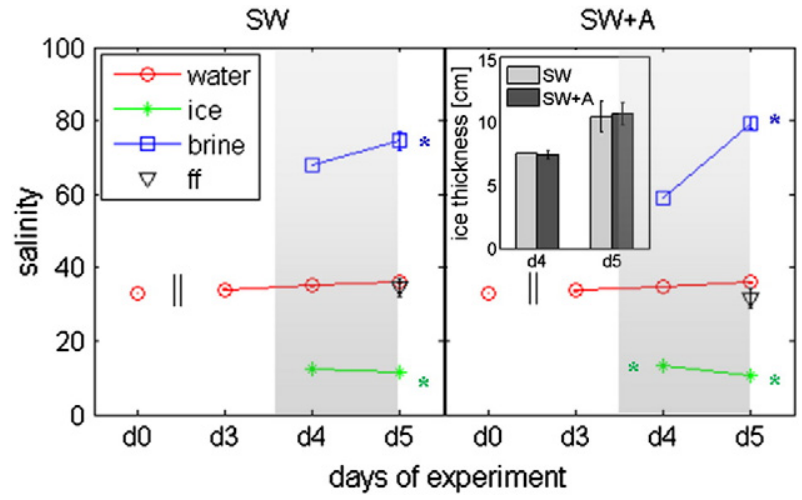

Fig. 4. The salinity in water, brine, bulk ice and frost flowers (ffs) over the time of the experiment for each treatment together with the ice thickness on $\mathrm{d} 4$ and $\mathrm{d} 5$. Error bars show the standard error (SE) among replicated mesocosms $(n=1-8)$. Significant differences in salinity $(t$-test for $n>1, p<0.05$ ) of brine, bulk ice or frost flowers compared to water are indicated by *. The grey shading indicates the freezing phase of the experiment. The treatments with North Sea water alone and with algal-DOM are labeled SW and SW + A, respectively. The inset shows the mean ice thickness of SW and $\mathrm{SW}+\mathrm{A}$ at $\mathrm{d} 4$ and $\mathrm{d} 5$ with the SE represented by error bars. were not consistent in both treatments suggesting that freezing did not change spectral slopes in a consistent manner (Fig. 7e-j).

In the LC-SEC analysis, the variation in the UV absorbance at $\mathrm{Rt}<13.5$ min did not exceed the standard deviation of the replicated measurements (Fig. 2c). The later parts of the chromatograms ( $\mathrm{Rt}=13.5$ to $15.5 \mathrm{~min}$ ) varied most and therefore we examined $\mathrm{Rt}$ and absorbance values of P1 and P2 found in this region of the chromatogram in detail (Figs. 2c, 10). The intensities of P1 and P2 were not significantly different between water and bulk ice, brine or frost flowers (Fig. 10e-h). Rts of P1 and P2 were often longer in bulk ice, brine and frost flowers than in water (Fig. 10a-d) indicating shift in the molecular mass distribution of DOM towards smaller molecules.

\subsection{Enrichment factors}

For further analysis of enrichment factors reported in Fig. 6, the EFs for humic type DOM (CDOM, C2, C3 and C4) and amino acid-like fluorophores ( $\mathrm{C} 1, \mathrm{C} 5$ and $\mathrm{C} 6$ ) were combined and examined with EFs for the other DOM fractions (Fig. 11). Among these DOM fractions, $E F$ (humics) ranged from 1.0 to 1.39 in different sample 

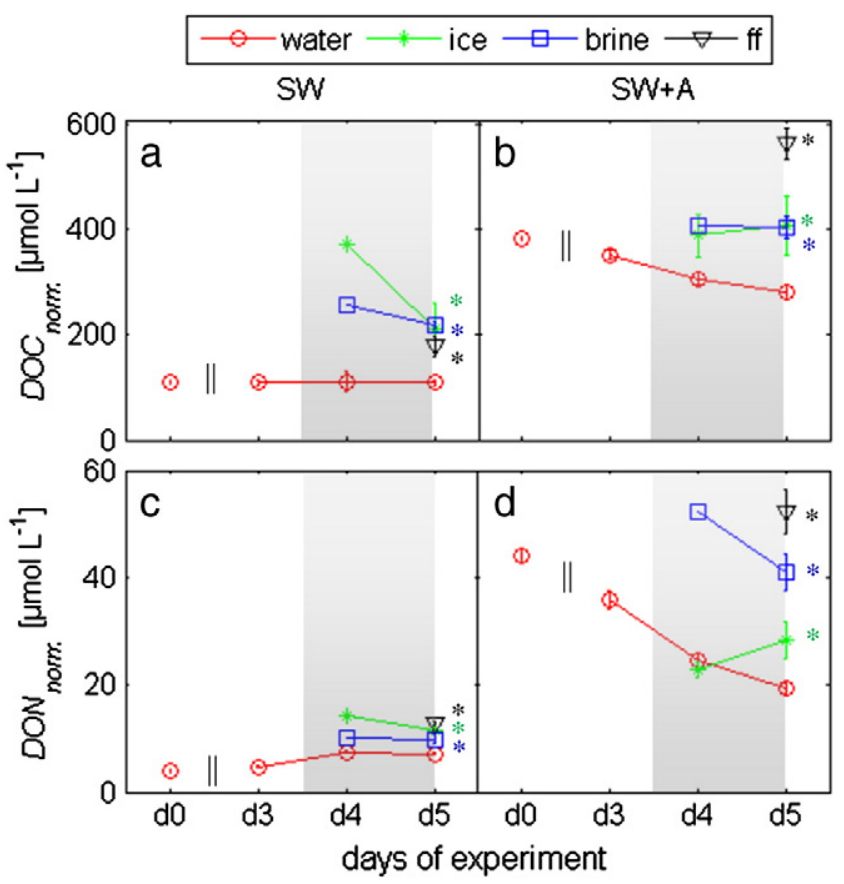

Fig. 5. Temporal development of DOC and DON after salinity normalization to 33. See Fig. 4 for more detailed explanation.

types. The highest EFs and highest variability among replicates were found for amino acid-like DOM (see $E F(a a)$ in Fig. 11). The $E F(d C H O)$ and $E F(d U A)$ ranged from 0.73 to 2.69 (Fig. 11). These results indicate that although all fractions of DOM were generally enriched in newly formed ice, the degree of enrichment differed between the various DOM fractions.

EFs were generally lower in the treatment with algal-DOM than in the treatment without it (Fig. 11; independent samples t-test; $\mathrm{p}<0.05$ ). Enrichment of DOM was generally lower in the brines compared with the bulk ice samples (Fig. 11; independent samples t-test; $\mathrm{p}<0.05$ ). In brines, the EFs were sometimes below 1.0 (e.g., $E F(d U A$, brine $)=0.73$ ) indicating a depletion of DOM compared to water. EFs were higher in frost flowers $(2.26 \pm 0.26$, mean \pm SE for all DOM fractions) compared with bulk ice or brines (independent samples $t$-test; $\mathrm{p}<0.05$ ). These results indicate that EFs in frost flowers were up to 4 times higher than those in bulk ice samples and 7 times higher than in brines ( $E F(C 6)$, Fig. $6 r$ ).

\section{Discussion}

\subsection{Selective incorporation of DOM fractions during ice formation}

The present study investigated the behavior of different DOM fractions in bulk ice, brine and frost flowers during initial ice formation. The results show that all investigated DOM fractions (DOC, DON, CDOM, FDOM, dCHO, dUA) are generally enriched in bulk ice when normalized to the salinity of water. As in our study, enrichment of CDOM, DOC and DON has been observed in natural ice of unknown age in the Baltic Sea (Granskog et al., 2004; Stedmon et al., 2007) and the Southern Ocean (Meiners et al., 2009; Stedmon et al., 2011; Underwood et al., 2010; Norman et al., 2011). Since our results concern new ice ( $<2$ days old), they indicate that DOM is enriched already during the formation of ice mainly through abiotic physico-chemical processes.

Natural older sea ice can have $E F(D O C$, bulk ice) of approximately $6.71 \pm 2.10$ and $E F(D O N$, bulk ice) as high as $11.58 \pm 5.70$ (calculated from Norman et al., 2011). The values in new ice measured experimentally in the present study are substantially lower (EF(DOC, bulk

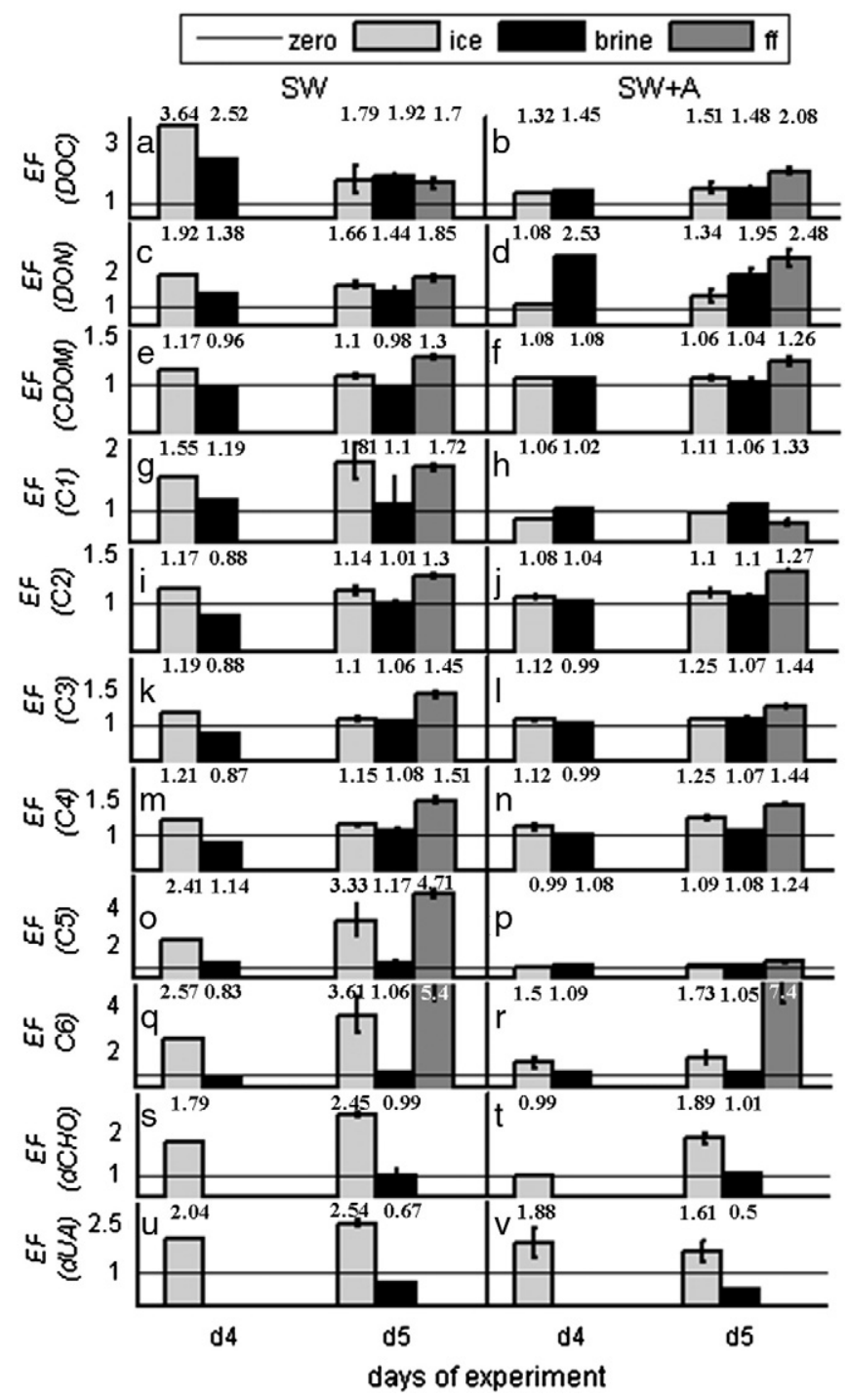

Fig. 6. Enrichment factor (EF) of DOC, $\mathrm{DON}, \mathrm{a}_{\mathrm{CDOM}, 255 \mathrm{~nm}}$, fluorescent components $\mathrm{C} 1$ to $\mathrm{C} 6, \mathrm{dCHO}$ and dUA in bulk ice (light grey), brine (black), and frost flowers (dark grey) on d4 and d5 (see Eq. (4)). The black line visualizes the point of zero enrichment. Error bars show the standard error among replicated mesocosms $(n=1-3)$. Numbers on top of each bar show the mean EF. Please note the different scales.

ice $)=2.25 \pm 0.48 ; E F(D O N$, bulk ice $)=1.72 \pm 0.11)$. This likely reflects the contribution of autochthonous production in natural ice (Fig. 11, Stedmon et al., 2007; Norman et al., 2011).

The enrichment of CDOM in this study $(E F(C D O M$, bulk ice $)=$ $1.12 \pm 0.03)$ is similar to that in young ice formed in brackish Baltic Sea water $(E F(C D O M$, bulk ice $)=1.34 \pm 0.16$; Müller et al., 2011). Similar to the patterns seen for CDOM, fluorescent components related to humic substances also have low EFs between 1.16 and 1.27 in young ice formed from water of the Baltic Sea and the North Sea (Müller et al., 2011, this study). In both studies the amino-acid-like components had the highest EFs among the FDOM-components examined: 1.53 in the Baltic Sea (Müller et al. 2011) and $2.72 \pm 0.47$ in the North Sea (present study). The mean of $E F(d C H O$, bulk ice) and $E F(d U A$, bulk ice) of $1.9 \pm 0.191$ in our study is similar to $1.61 \pm 0.3$ for exopolymers in newly formed artificial sea ice (Ewert and Deming, 2011). When our results are combined with earlier studies (Ewert and Deming, 2011; Müller et al., 2011), it seems that the degree of enrichment depends on the chemical characteristics of DOM with the lowest enrichment for humic type-DOM and highest enrichment for amino acid-like DOM. 

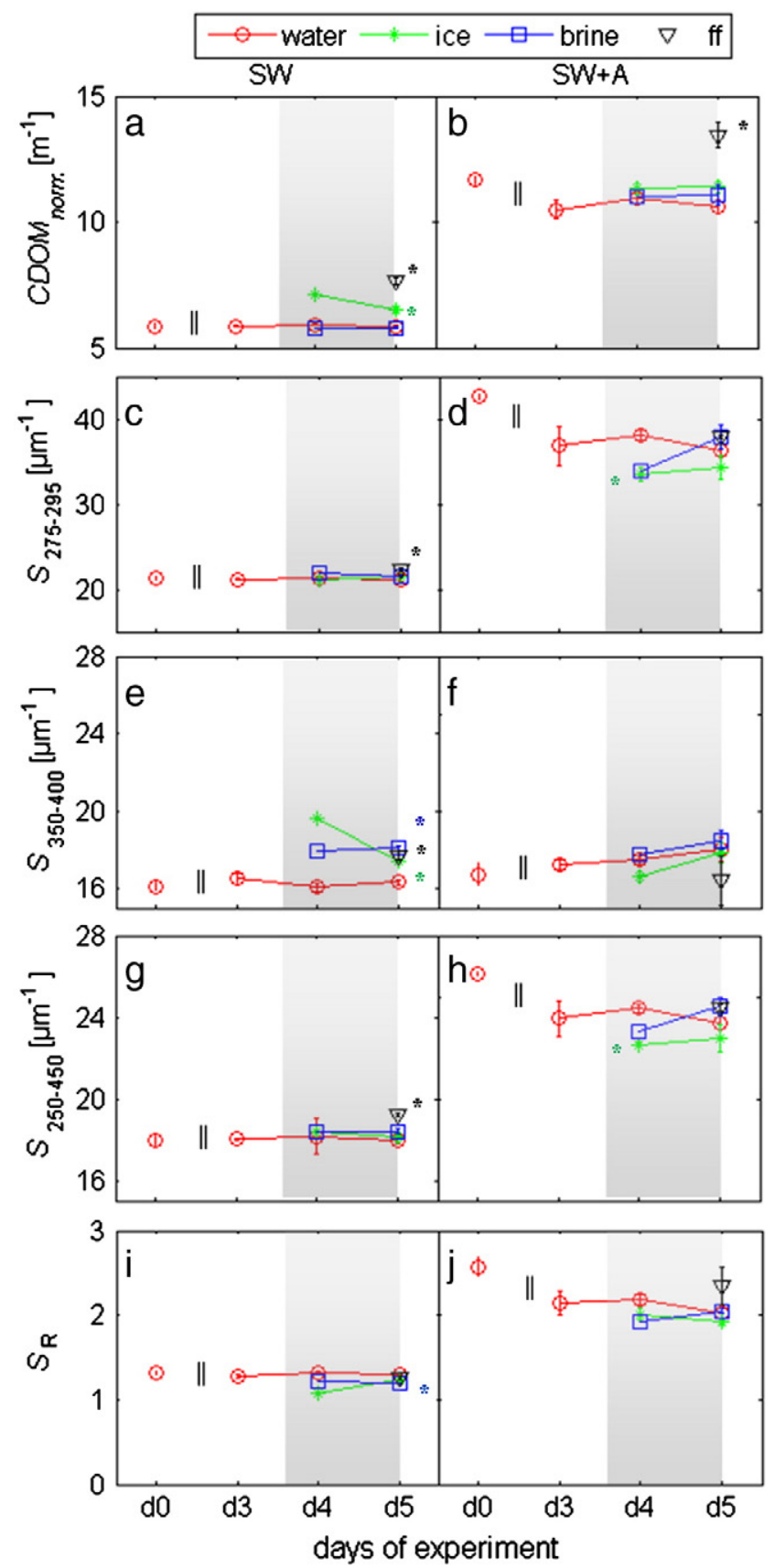

Fig. 7. Temporal development of absorption coefficient of CDOM at $255 \mathrm{~nm}$ normalized to water salinity, $C D O M_{\text {norm }}$ (a-b), the spectral slope coefficient $S_{275-295}$ (c-d), $S_{350-400}$ $(\mathrm{e}-\mathrm{f}), S_{250-450}(\mathrm{~g}-\mathrm{h})$ and $S_{\mathrm{R}}$ values $(\mathrm{i}-\mathrm{j})$. The notation used and the salinity normalization are explained in Fig. 4 and Eq. (3), respectively.

\subsection{Is there a mechanistic explanation for the enrichment of DOM in new sea ice?}

This study revealed that while DOM is incorporated in newly formed sea ice, the size distribution of humic-like DOM changes towards smaller molecules. We are not aware of other studies, which have measured changes in the molecular size distribution of DOM during freezing. However, earlier studies concerning the freeze fractionation of inorganic ions have suggested that freezing rejects preferably smaller ions with larger diffusion coefficients (e.g., $2 \times 10^{-9} \mathrm{~m}^{2} \mathrm{~s}^{-1}$ for $\mathrm{K}^{+}$) than larger ions with smaller diffusion coefficients (e.g., $0.5 \times 10^{-9} \mathrm{~m}^{2} \mathrm{~s}^{-1}$ for $\mathrm{SO}_{4}^{2-}$; Granskog et al., 2004; Maus et al., 2011). The diffusion coefficients of humic-like DOM, shown in our analyses, can range over

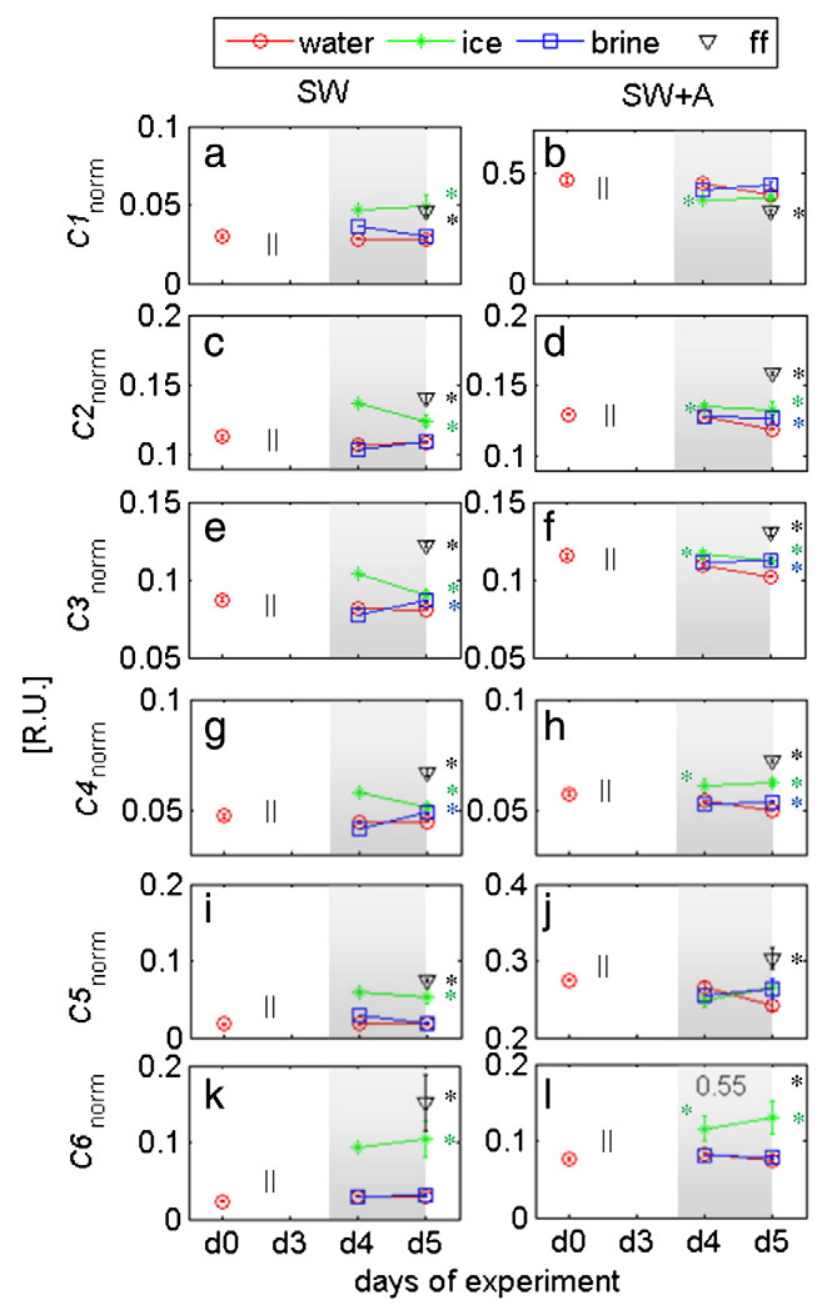

Fig. 8. Temporal development in the intensity of maximum fluorescence of the components 1 to 6 after salinity normalization to 33. Note the different scales between the treatments for $\mathrm{C} 1$ and $\mathrm{C} 5$ as well as the off-scale value 0.55 for frost flowers in panel l. See Fig. 4 for more detailed explanation.

four-fold like those of major inorganic ions in seawater (Hassellöv, 2005; Siripinyanond et al., 2005). If diffusion plays a major role in the process of selective rejection of DOM as suggested for inorganic ions, we should have observed a shift towards larger molecules in the samples collected from ice in our LC-SEC measurements. On the contrary, our study indicates a shift towards smaller molecules in the molecular size distribution of DOM during incorporation to sea ice. This indicates that diffusion cannot be the major factor that controls the selective rejection of humic-like DOM in ice. Additionally, according to Aslam et al. (2012b) different size-classes of dCHOs enrich similarly to the new sea ice. Hence, this study and that of Aslam et al. (2012b) indicate that freezing changes the molecular size of distribution of DOM only little when DOM from seawater is incorporated in newly formed sea ice.

Both dUAs and dCHO examined in this study are part of the pool of material that also included dissolved EPS and transparent exopolymeric particles (TEP) and can result in the coagulation of DOM and potentially enhance the enrichment of DOM in sea ice (Chin et al., 1998; Engel et al., 2004; Verdugo et al., 2004). In our experiment, the addition of algal-DOM doubled the concentration of dUA and $\mathrm{dCHO}$ in the $\mathrm{SW}+\mathrm{A}$ treatment compared to the SW-treatment. The enrichment of DOM would have been expected to be higher in the algal-DOM treatment if dUA and dCHO enhance enrichment of DOM (Aslam et al., 2012b). Contrary to this expectation, EFs were lower in the SW + A than in the SW-treatment. Our 


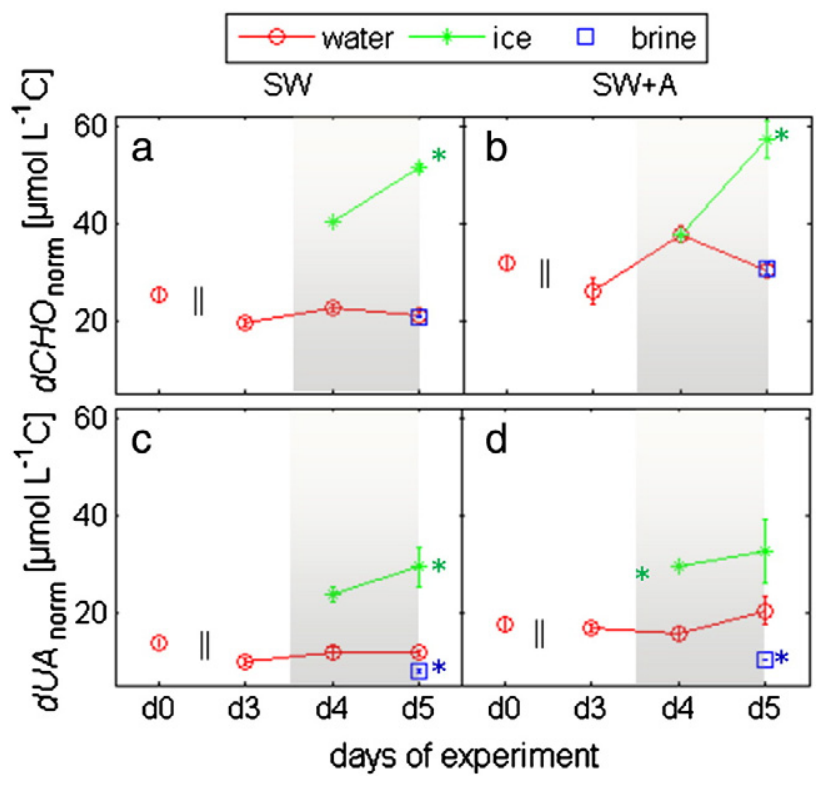

Fig. 9. Temporal development of salinity-normalized concentrations in dissolved carbohydrates (Fig. 8a-b) and dissolved uronic acids (Fig. 8c-d). See Fig. 4 for more detailed explanation.

observation suggests that dUA and $\mathrm{dCHO}$ did not influence enrichment of DOM during the initial formation of ice, but that does not exclude such possibility in older sea ice, where algal derived DOM and EPS would play more of a role than in these short term experiments.

In this study, the salinity normalized concentrations of DOM, and the EFs calculated from them, were lower in brine than in bulk ice, as also observed for natural sea ice in the Southern Ocean (Underwood et al., 2010; Norman et al., 2011). All three studies collected brine with the sackhole-technique (Papadimitriou et al., 2007). When a sackhole is filled with brine having an $E F(D O M$, brine) lower than in the original bulk ice, the $E F(D O M$, bulk ice) in the surrounding bulk ice must increase simultaneously in less than $30 \mathrm{~min}$, the time used for collection of brine in this study. Differences in the diffusion rates among solutes may not be able to explain such rapid changes in $E F(D O M)$ during the filling of a sackhole. One alternative potential mechanism is that there was selective drainage: i.e. brine from large brine channels, but with low $E F(D O M)$, drain more effectively into a sackhole than disconnected or very small brine channels with higher $E F(D O M)$. The change in $E F(D O M$, brine) may be also explained by a selective drainage of the most soluble solutes with low $E F(D O M)$ moving with a hydraulic flow to a sackhole. In this case, the less soluble solutes, or their insoluble forms in highly saline brine, will result in high $E F(D O M$, bulk ice). A poor solubility of DOM at high salinities may be explained e.g., by the association between multivalent cations and negatively-charged functional groups of DOM (Chave and Suess, 1970). In the latter case, both salts and DOM are converted to insoluble forms, which are likely overlooked when examining filtered samples alone (e.g., in the present study). If a similar drainage of brine with low $E F(D O M$, brine) into the under-ice water takes place during initial ice formation, it can result in the observed enrichment of the remaining DOM in new ice (Giannelli et al., 2001; Müller et al., 2011; this study).

Frost flowers are initially formed from water evaporating from brine into the colder atmosphere and only then, brine is drawn up onto the frost flower crystals by capillary actions (Perovich and Richter-Menge, 1994; Martin et al., 1996; Rankin et al., 2002). Therefore, depending on the temperature, the salinity of frost flowers can be as low as the seawater salinity in the early stage of frost flower formation, as found in the present experiment. Despite the low salinity
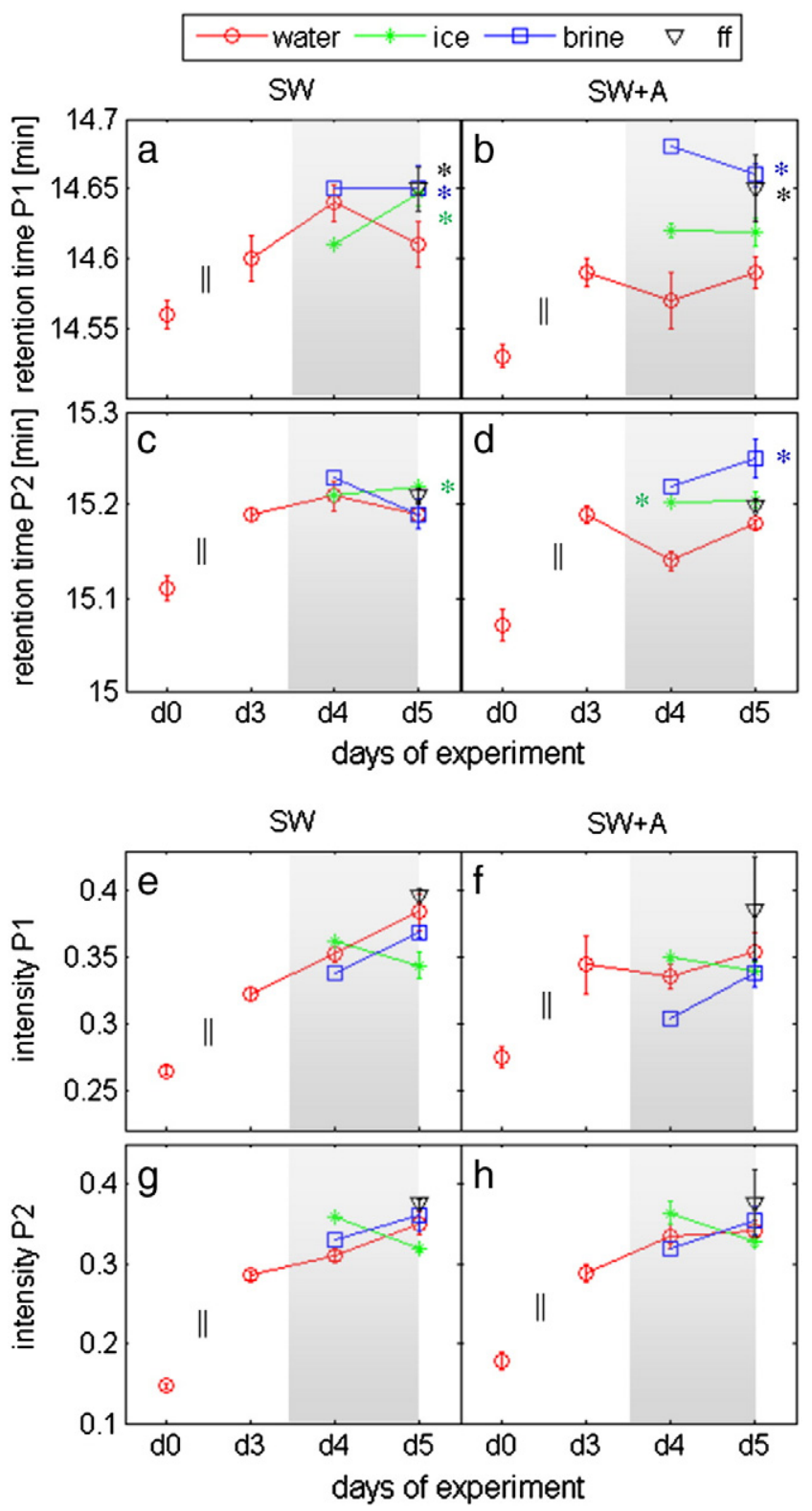

Fig. 10. The retention times (a-d) and absorbances (e-f) of peak 1 (P1) and 2 (P2) in the LC-SEC chromatograms. Full chromatograms are exemplified in Fig. 2c. See Fig. 4 for more detailed explanation.

in frost flowers, there was a significant enrichment of DOM compared to under-ice water and brine from North Sea water (Figs. 6, 11, Bowman and Deming, 2010; Aslam et al., 2012b). Hence, we suggest that there is a second selective rejection process that occurs during the rapid freezing of brine on the ice surface, similar to the process during sea ice formation.

In this study various components of DOM are enriched in ice relative to water, even in the treatment with algal-DOM, which increased the concentration of DOM (DON and amino acids in particular) in water. The introduction of such potentially biologically labile DOM increased microbial activity in water and sea ice of the SW + A treatment (Aslam et al., 2012b) resulting in a decrease of DOC and DON in water later in the experiment than the initial stages reported here. It is possible, that the observed changes in the EFs of labile DOM components and in the molecular mass distribution and $S_{250-450}$ during sea ice formation are at least partly related to elevated microbial activity in SW + A-treatment. 


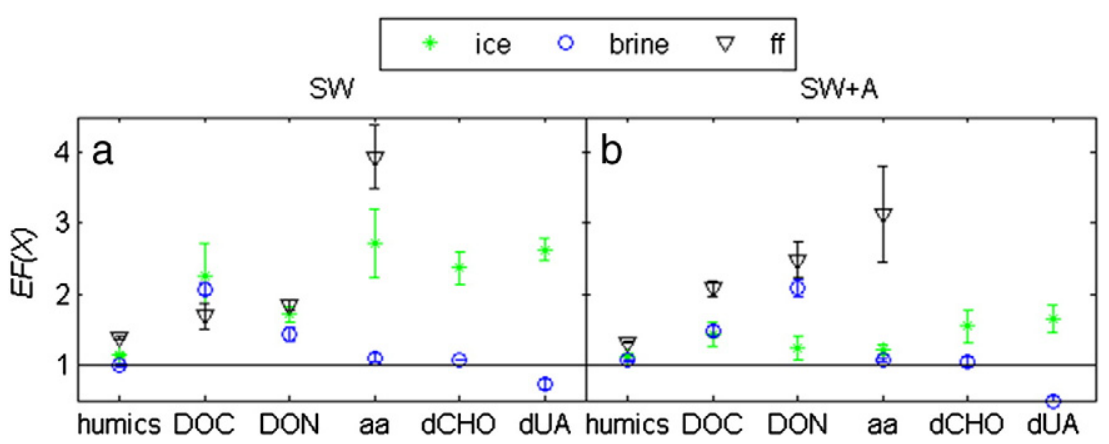

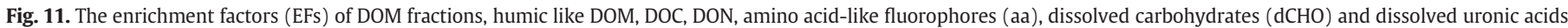

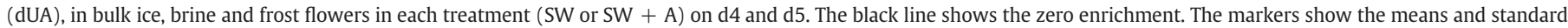
error among replicate mesocosms $(n=1-3)$.

\section{Conclusions}

This study shows that there is a quantitative enrichment for the whole DOM pool regardless of its initial concentration during initial freezing of seawater, which is probably based on a physico-chemical process. The enrichment factors vary between 1.0 and 1.39 for humic-like material, but are higher and more variable for amino-acid like DOM fractions. The results indicate that diffusion has only a minor effect on the enrichment process and also the concentration of carbohydrates in the seawater did not explain the enrichment behavior in this short-term experiment. Enrichment of DOM in melted ice differs from that in brine suggesting that the DOM concentration and composition vary among well-connected brine channels and the smallest brine channels and inclusions. These differences in the selective rejection of DOM from bulk ice and brine also mean that the method of sackhole sampling does not necessarily succeed in extracting brine that is representative of in situ conditions. Frost flowers had a similar DOM composition to that of the brines, but at higher concentration, relative to salt, suggesting that a second fractionation process occurs during frost flower formation.

\section{Acknowledgements}

The present study was supported by the European Community's Sixth Framework Programme through the grant to the budget of the Integrated Infrastructure Initiative HYDRALAB III, Contract no. 022441(RII3) and the Walter Andrée de Nottbeck Foundation. The authors would like to thank the Hamburg Ship Model Basin (HSVA), especially Kalle Evers and the ice tank crew, for the hospitality, technical and scientific support and the professional execution of the test program in the Research Infrastructure ARCTECLAB. We are indebted to Naomi Thomas for the unenviable task of producing the algal DOM additive and Erika Allhusen, AWI, for essential support for the setting up and successful execution of the experiment. GJCU, SNA and DNT were partly funded by the U.K. Natural Environment Research Council, grant NE/D00681/1 and CAS was partly funded by the Carlsberg Foundation.

\section{References}

Aslam, S.N., Cresswell-maynard, T., Thomas, D.N., Underwood, G.J.C., 2012a. Production and characterization of the intra- and extracellular carbohydrates and polymeric substances (EPS) of three sea-ice diatom species, and evidence for a cryoprotective role for EPS. J. Phycol. 48, 1494-1509. http://dx.doi.org/10.1111/jpy.12004.

Aslam, S., Underwood, G.J.C., Kaartokallio, H., Norman, P.K., Autio, R., Fischer, M., Kuosa, H., Dieckmann, G.S., Thomas, D.N., 2012b. Dissolved extracellular polymeric substance (dEPS) dynamics and bacterial growth during sea ice formation in an ice tank study. Polar Biol. 35, 661-676. http://dx.doi.org/10.1007/s00300-011-1112-0.
Bellinger, B.J., Abdullahi, A.S., Gretz, M.R., Underwood, G.J.C., 2005. Biofilm polymers: relationship between carbohydrate biopolymers from estuarine mudflats and unialgal cultures of benthic diatoms. Aquat. Microb. Ecol. 38, 169-180.

Bowman, J.S., Deming, J.W., 2010. Elevated bacterial abundance and exopolymers in saline frost flowers and implications for atmospheric chemistry and microbial dispersal. Geophys. Res. Lett. 37, L13501. http://dx.doi.org/10.1029/2010GL043020.

Chave, K.E., Suess, E., 1970. Calcium carbonate saturation in seawater: effects of dissolved organic matter. Limnol. Oceanogr. 633-637.

Chin, W.-C., Orellana, M.V., Verdugo, P., 1998. Spontaneous assembly of marine dissolved organic matter into polymer gels. Nature 391 (5), 568-572.

Coble, P., 1996. Characterization of marine and terrestrial DOM in seawater using excitation-emission matrix spectroscopy. Mar. Chem. 51, 325-346.

Engel, A., Thoms, S., Riebesell, U., Rochelle-Newall, E., Zondervan, I., 2004. Polysaccharide aggregation as a potential sink of marine dissolved organic carbon. Nature 428, 929-932.

Ewert, M., Deming, J.W., 2011. Selective retention in saline ice of extracellular polysaccharides produced by the cold-adapted marine bacterium Colwellia psychrerythraea strain 34H. Ann. Glaciol. 52 (57), 111-117.

Giannelli, V., Thomas, D.N., Haas, C., Kattner, G., Kennedy, H., Dieckmann, G.S., 2001 Behaviour of dissolved organic matter and inorganic nutrients during experimental sea-ice formation. Ann. Glaciol. 33 (1), 317-321. http://dx.doi.org/ $10.3189 / 172756401781818572$.

Granskog, M.A., Virkkunen, K., Thomas, D.N., Ehn, J., Kola, H., Martma, T., 2004. Chemical properties of brackish water ice in the Bothnian Bay, the Baltic Sea. J. Glaciol. 50 (169), 292-302. http://dx.doi.org/10.3189/172756504781830079.

Grasshoff, K., Ehrhardt, M., Kremling, K., 1983. Methods of Seawater Analysis. Verlag Chemie, Weinheim.

Gross, G.W., Gutjahr, A., Caylor, K., 1987. Recent experimental work on solute redistribution at the ice/water interface. Implications for electrical properties and interface processes. J. Phys. 527-533.

Hassellöv, M., 2005. Relative molar mass distributions of chromophoric colloidal organic matter in coastal seawater determined by Flow Field-Flow Fractionation with UV absorbance and fluorescence detection. Mar. Chem. 94, 111-123. http:// dx.doi.org/10.1016/j.marchem.2004.07.012.

Helms, J.R., Stubbins, A., Ritchie, J.D., Minor, E.C., Kieber, D.J., Mopper, K., 2008. Absorption spectral slopes and slope ratios as indicators of molecular weight, source, and photobleaching of chromophoric dissolved organic matter. Limnol. Oceanogr. 53 (3), 955-969.

Her, N., Amy, G., Foss, D., Cho, J., Yoon, Y., Kosenka, P., 2002. Optimization of method for detecting and characterizing NOM by HPLC-size exclusion chromatography with UV and on-line DOC detection. Environ. Sci. Technol. 36 (5), 1069-1076.

Krembs, C., Eicken, H., Deming, J.W., 2011. Exopolymer alteration of physical properties of sea ice and implications for ice habitability and biogeochemistry in a warmer Arctic. Proc. Natl. Acad. Sci. U. S. A. 108 (9), 3653-3658. http:// dx.doi.org/10.1073/pnas.1100701108.

Lawaetz, A.J., Stedmon, C.A., 2009. Fluorescence intensity calibration using Raman scatter peak of water. Appl. Spectrosc. 63, 936-940. http://dx.doi.org/10.1366/ 000370209788964548.

Martin, S., Yu, Y., Drucker, R., 1996. The temperature dependence of frost flower growth on laboratory sea ice and the effect of the frost flowers on infrared observations of the surface. J. Geophys. Res. 101 (C5), 12,111-12,125.

Maus, S., Müller, S., Büttner, J., Brütsch, S., Huthwelker, T., Schwikowski, M., et al., 2011. Ion fractionation in young sea ice from Kongsfjorden, Svalbard. Ann. Glaciol. 52 (57), 301-310.

Meiners, K.M., Papadimitriou, S., Thomas, D.N., Norman, L., Dieckmann, G.S., 2009 Biogeochemical conditions and ice algal photosynthetic parameters in Weddel Sea ice during early spring. Polar Biol. 32, 1055-1065. http://dx.doi.org/10.1007/ s00300-009-0605-6.

Minor, E.C., Simjouw, J.-P., Boon, J.J., Kerkhoff, A.E., Van Der Horst, J., 2002. Estuarine/ marine UDOM as characterized by size-exclusion chromatography and organic mass spectrometry. Mar. Chem. 78, 75-102.

Müller, S., Vähätalo, A., Granskog, M.A., Autio, R., Kaartokallio, H., 2011. Behaviour of dissolved organic matter during formation of natural and artificially grown Baltic Sea ice. Ann. Glaciol. 52 (57), 233-241. 
Murphy, K.R., Stedmon, C.A., Waite, T.D., Ruiz, G.M., 2008. Distinguishing between terrestrial and autochthonous organic matter sources in marine environments using fluorescence spectroscopy. Mar. Chem. 108 (1-2), 40-58. http://dx.doi.org/ 10.1016/j.marchem.2007.10.003.

Norman, L., Thomas, D.N., Stedmon, C.A., Granskog, M.A., Papadimitriou, S., Krapp, R.H 2011. The characteristics of dissolved organic matter (DOM) and chromophoric dissolved organic matter (CDOM) in Antarctic sea ice. Deep-Sea Res. II 58 (9-10), 1075-1091. http://dx.doi.org/10.1016/j.dsr2.2010.10.030.

Papadimitriou, S., Thomas, D.N., Kennedy, H., Haas, C., Kuosa, H., Krell, A., et al., 2007. Biogeochemical composition of natural sea ice brines from the Weddell Sea during early austral summer. Limnol. Oceanogr. 52 (5), 1809-1823.

Patsayeva, S., Reuter, R., Thomas, D.N., 2004. Fluorescence of dissolved organic matter in seawater at low temperatures and during ice formation. EARSeL eProceedings 2 227-238.

Perovich, D.K., Richter-Menge, J.A., 1994. Surface characteristics of lead ice. J. Geophys. Res. 99 (16), 341-350.

Petrich, C., Eicken, H., 2010. Growth, Structure and Properties of Sea Ice, In: Thomas, D.N. Dieckmann, G.S. (Eds.), Sea Ice, 2nd ed. Wiley-Blackwell, Oxford, U.K., pp. 23-77.

Qian, J.G., Mopper, K., 1996. Automated high performance, high-temperature combustion total organic carbon analyzer. Anal. Chem. 68, 3090-3097.

Rankin, A.M., Wolff, E.W., Seelye, M., 2002. Frost flowers: implications for tropospheric chemistry and ice core interpretation. J. Geophys. Res. 107, 4683. http://dx.doi.org/ 10.1029/2002JD002492.

Raymond, J.A., Fritsen, C., Shen, K., 2007. An ice-binding protein from an Antarctic sea ice bacterium. FEMS Microbiol. Ecol. 61, 214-221. http://dx.doi.org/10.1111/ j.1574-6941.2007.00345.x

Reeburgh, W.S., Springer-Young, M., 1983. New measurements of sulfate and chlorinity in natural sea ice. J. Geophys. Res. 88 (C5), 2959-2966.

Siripinyanond, A., Worapanyanond, S., Shiowatana, J., 2005. Field-flow fractionationinductively coupled plasma mass spectrometry: an alternative approach to investigate metal-humic substances interaction. Environ. Sci. Technol. 39, 3295-3301.

Specht, Christian H., Frimmel, F.H., 2000. Specific interactions of organic substances in size-exclusion chromatography. Environ. Sci. Technol. 34 (11), 2361-2366.
Stedmon, C.A., Bro, R., 2008. Characterizing dissolved organic matter fluorescence with parallel factor analysis: a tutorial. Limnol. Oceanogr. Methods 6, 572-579.

Stedmon, C.A., Markager, S., 2005. Tracing the production and degradation of autochthonous fractions of dissolved organic matter using fluorescence analysis. Limnol. Oceanogr. 50 (5), 1415-1426. http://dx.doi.org/10.4319/lo.2005.50.5.1415.

Stedmon, C., Markager, S., Kaas, H., 2000. Optical properties and signatures of chromophoric dissolved organic matter (CDOM) in Danish coastal waters. Estuarine Coastal Shelf Sci. 51, 267-278. http://dx.doi.org/10.1006/ecss.2000.0645.

Stedmon, C.A., Thomas, D.N., Granskog, M., Kaartokallio, H., Papadimitriou, S., Kuosa, H., 2007. Characteristics of dissolved organic matter in Baltic coastal sea ice: allochthonous or autochthonous origins? Environ. Sci. Technol. 41 (21), 7273-7279.

Stedmon, C.A., Thomas, D.N., Papadimitriou, S., Granskog, M.A., Dieckmann, G.S., 2011. Using fluorescence to characterize dissolved organic matter in Antarctic sea ice brines. J. Geophys. Res. 116 (G03027). http://dx.doi.org/10.1029/2011JG001716.

Thomas, D.N., Dieckmann, G.S., 2002. Antarctic Sea ice - a habitat for extremophiles. Science, 295 (5555), 641-644. http://dx.doi.org/10.1126/science.1063391.

Thomas, D.N., Dieckmann, G.S., 2010. Sea Ice, 2nd edition. Wiley-Blackwell, Oxford, U.K.

Underwood, G., Fietz, S., Papadimitriou, S., Thomas, D.N., Dieckmann, G.S., 2010. Distribution and composition of dissolved extracellular polymeric substances (EPS) in Antarctic sea ice. Mar. Ecol. Prog. Ser. 404, 1-19. http://dx.doi.org/10.3354/meps08557.

Uusikivi, J., Vähätalo, A.V., Granskog, M.A., Sommaruga, R., 2010. Contribution of mycosporine-like amino acids and colored dissolved and particulate matter to sea ice optical properties and ultraviolet attenuation. Limnol. Oceanogr. 55 (2), 703-713.

Vancoppenolle, M., Goosse, H., Montety, A.D., Fichefet, T., Tremblay, B., Tison, J.-L., 2010. Modeling brine and nutrient dynamics in Antarctic sea ice: the case of dissolved silica. J. Geophys. Res. 115 (C02005). http://dx.doi.org/10.1029/2009JC005369.

Verdugo, P., Alldredge, A.L., Azam, F., Kirchman, D.L., Passow, U., Santschi, P.H., 2004. The oceanic gel phase: a bridge in the DOM-POM continuum. Mar. Chem. 92 (1-4), 67-85. http://dx.doi.org/10.1007/s00289-006-0615-2.

Yamashita, Y., Cory, R.M., Nishioka, J., Kuma, K., Tanoue, E., Jaffe, R., 2010. Fluorescence characteristics of dissolved organic matter in the deep waters of the Okhotsk Sea and the northwestern North Pacific Ocean. Deep-Sea Res. II 57, 1478-1485. http://dx.doi.org/10.1016/j.dsr2.2010.02.016. 